\title{
Open Access, Open Systems: Pastoral Management of Common-Pool Resources in the Chad Basin
}

\author{
Mark Moritz • Paul Scholte • Ian M. Hamilton • Saïdou Kari
}

Published online: 5 February 2013

(C) Springer Science+Business Media New York 2013

\begin{abstract}
The discussion about the impact of pastoralists on ecosystems has been profoundly shaped by Hardin's tragedy of the commons that held pastoralists responsible for overgrazing the range. Research has shown that grazing ecosystems are much more complex and dynamic than was previously assumed and that they can be managed adaptively as commons. However, proponents and critics of Hardin's thesis continue to argue that open access to common-pool resources inevitably leads to a tragedy of the commons. A longitudinal study that we conducted of pastoral mobility and primary production in the Logone floodplain in the Far North Region of Cameroon suggest that open access does not have to lead to a tragedy of the commons. We argue that this pastoral system is best conceptualized as an open system, in which a combination of individual decision-making and co-
\end{abstract}

\footnotetext{
M. Moritz $(\bowtie)$

Department of Anthropology, The Ohio State University,

$174 \mathrm{~W} 18$ th Avenue,

Columbus, OH 43210-1106, USA

e-mail: mark.moritz@gmail.com

P. Scholte

c/o Nieuwe Teertuinen 12C,

Amsterdam, LV 1013, Netherlands

e-mail: Pault.scholte@gmail.com

I. M. Hamilton

Department of Evolution, Ecology and Organismal Biology,

Department of Mathematics, The Ohio State University,

390 Aronoff Laboratory, 318 W. 12th Avenue,

Columbus, OH 43210, USA

e-mail: hamilton.598@osu.edu

S. Kari

Centre d'Appui a la Recherche et au Pastoralisme (CARPA),

BP 383, Maroua, Cameroon

e-mail: saidoukari@yahoo.fr
}

ordination of movements leads to an ideal-free type of distribution of mobile pastoralists. We explain how this selforganizing system of open access works and its implications for theories of management of common-pool resources and our understanding of pastoral systems.

Keywords Open access · Common-pool resources · Pastoral systems $\cdot$ Chad Basin

\section{Introduction}

The discussion about the impact of pastoralists on ecosystems has been profoundly shaped by Hardin's (1968) tragedy of the commons hypothesis that held pastoralists responsible for overgrazing the range. Hardin's argument focused on how population growth, in particular the freedom to breed, threatens our planet. Hardin gave an example of shepherds who keep their privately owned herds on pastures that are held in commons. He argued that it is in the economic interest of each individual herder to increase the size of the herd because they can gain all the benefits of additional animals while sharing the costs of using the pastures with other herders. When all herders follow this strategy, Hardin argued, it will inevitably lead to degradation, i.e., a tragedy of the commons.

Hardin's thesis has been challenged by political scientists and anthropologists (Feeny et al. 1990; McCay and Acheson 1987; Ostrom 1990; Ostrom et al. 2002). One of the main critiques has been that he confused commons with open access or unmanaged common-pool resources (McCay and Acheson 1987; Ostrom 1990). Common-pool resources are valued resources that are "available to more than one person and subject to degradation as a result of overuse. Common-pool resources are ones for which exclusion from 
the resource is costly and one person's use subtracts from what is available to others" (Dietz et al. 2002). Four different types of property regimes of common-pool resources have been recognized: open access, public or state property, common property, and private property. In common property regimes a specific user group has use rights over the resource, while in open access situations no property rights are defined leading to a "free for all" (Dietz et al. 2002).

Ostrom (1990) has shown that common-pool resources can be managed sustainably as common property regimes. She also generated design principles for successful common property regimes that can be categorized as follows: 1) membership rules that define who can use the resources, their rights and responsibilities; 2) appropriation rules that specify how much of what type of resources can be extracted, or the condition of the resource after extraction; and 3) procedural rules that empower monitoring, sanctioning, arbitration and negotiation (Niamir-Fuller 1999b). Since Ostrom published the design-principles, case studies, comparative studies, experiments, and meta-analyses have yielded more variables (Agrawal 2002; Ostrom et al. 2002; Poteete et al. 2010), resulting in a more complex diagnostic framework for the study of social-ecological systems (Ostrom 2007). Despite a well-developed theoretical framework, it has been challenging to develop general explanations for successful commons that hold across resources systems, primarily because of the complexity of both social and ecological systems and the configurational nature of the multitude of multidimensional variables (Agrawal 2002; Ostrom 2007; Poteete et al. 2010). However, both theoretical paradigms, i.e., Tragedy of the Commons and Governing the Commons, continue to argue that open access to common-pool resources will lead to a tragedy.

Both theoretical paradigms have shaped our understanding of how pastoralists interact with common-pool grazing resources. Hardin's shepherds' parable forever linked pastoralists with the tragedy of the commons. In sub-Saharan Africa, for example, pastoralists have been held responsible for overgrazing the range, exacerbating the hardship they endured during the droughts of the early 1970s and 1980s (Lamprey 1983; Picardi and Seifert 1976; Sinclair and Fryxell 1985). As a result researchers of African pastoral systems have had to explain that often there is no evidence of a tragedy of the commons (Horowitz 1986; McCabe 1990) or that it is the result of outside interventions (Ensminger and Knight 1997; Galaty 1994; Peters 1994). McCabe (1990), for example, has shown how the Turkana in Kenya manage common-pool resources and avoid a tragedy of the commons through a combination of mobility, regulation of access to grazing resources through private ownership of wells, and environmental constraints on herd size. Longitudinal, interdisciplinary studies of pastoral systems have also shown that grazing ecosystems are more complex and dynamic than previously assumed and that they can be managed adaptively as commons (Behnke and Scoones 1993; Niamir-Fuller 1999b).

The current consensus is that in most cases common-pool resources are managed as common property regimes, but that open access leads to a tragedy of the commons (Galvin 2009; Homewood 2008). Others have argued that there are no pastoral systems that operated according to the open access paradigm (Lane 1998; McCabe 1990). However, this understanding is primarily based on research in East Africa, which has dominated the literature (Fratkin et al. 1994; Galvin 2009). Consequently, the East African commons model is assumed to be applicable to other pastoral systems in sub-Saharan Africa (Mwangi and Ostrom 2009).

West African pastoral systems do not necessarily fit this East African model of the commons. There are only few clear cases of common property regimes in West Africa, for example, the oft-cited system of the diina in the Inner Niger Delta in Niger, which has been imposed by a strong pre-colonial state (Legrosse 1999). Instead it has been argued that in West African pastoral systems access to common-pool grazing resources is regulated through a number of informal institutions, social networks, and norms of reciprocity that are characterized by flexibility, porosity, and malleability (Bassett and Turner 2007; Fernández-Giménez and Le Febre 2006; Turner 1999). However, it is not at all clear whether and how these norms, networks, and institutions regulate access to and use of common-pool resources. We think that in many cases these systems are best described as open access because there are de facto no restrictions on access and use, but that researchers may (unconsciously) have been searching for some regulation as evidence of common property regimes where there is none, and afraid to use the label open access because of all its negative connotations.

Here we argue that the commons model may well describe many pastoral systems in East Africa, but not necessarily those in West and Central Africa, many of which have open access (Niamir-Fuller 1999a; Swallow 1990). Moreover, our longitudinal study of pastoral mobility and primary production in the Logone Floodplain in the Far North Region of Cameroon shows that open access does not have to lead to a tragedy of the commons (Scholte et al. 2006). Here we explain how this self-organizing system of management of open access works and discuss its implications for theories of management of common-pool resources and our understanding of pastoral systems.

\section{Methodology}

This article is based on 20 years of research with mobile pastoralists in the Far North Region of Cameroon (19932012), in particular on two long-term research projects of pastoral mobility in the Logone floodplain as well as on 
parallel ecological studies. The first study (1993-1999) focused on how the reflooding of the Logone floodplain led to an increase in perennial grasses and thereby increase in rangeland production and quality (Scholte et al. 2006). We documented the responses of mobile pastoralists by studying their transhumance patterns in five different years between 1993 and 1999 using transhumance surveys in which we surveyed the whole population, i.e., all mobile pastoralists that used our study area at some point during the year, and asked them the names and number of days of all the sites they had stayed in the previous year. We also recorded the number of pastoral households and estimated the size of the herds (Table 1).

In the second study (2008-2012), we examined how pastoralists coordinate their movements and avoid conflicts with each other using a combination of spatial and ethnographic analyses. We continued the transhumance surveys with the whole population of mobile pastoralists. In addition, we used GPS/GIS technology to map the locations of mobile pastoralists in the Logone floodplain and beyond. Four times a year we took the geographic coordinates of pastoral households (February, May, August, November). We used a combination of participant observation and informal, semi-structured and structured interviews to understand how pastoralists regulate access to and use of common-pool grazing resources in the Logone Floodplain.

Parallel to these studies we have conducted extensive research on the vegetation of the Logone floodplain between 1993 and 2003. A total of 199 plots, including 29 already studied in 1985 and 1986, were used to annually monitor changes in vegetation composition. Above-ground biomass has been measured as function of flooding depth in 32 , 8 and 16 plots in respectively 1994, 1995 and 1996. In addition, forage quality and below-ground biomass has been assessed in respectively 1996 and 1994, 1995. The results of these studies, on which we build our argument regarding the lack of overgrazing, have been published elsewhere (Scholte 2007; Scholte et al. 2000).

\section{Study Area and Population}

Two phytogeographic zones characterize the Far North Region of Cameroon: Sudanian in the southern grades and Sahelian in the Logone Floodplain (Fig. 1). The Logone Floodplain, called Yaayre in Fulfulde, is flooded by the Logone River and its branches from September until November. After the water recedes in December, thousands of Arab and FulBe pastoralists from Cameroon, Nigeria and Niger move with more than 200,000 cattle into the floodplain making it one of the most important dry season grazing lands in the Chad Basin (Seignobos and Iyébi-Mandjek 2000). Many remain there until the start of the rainy season

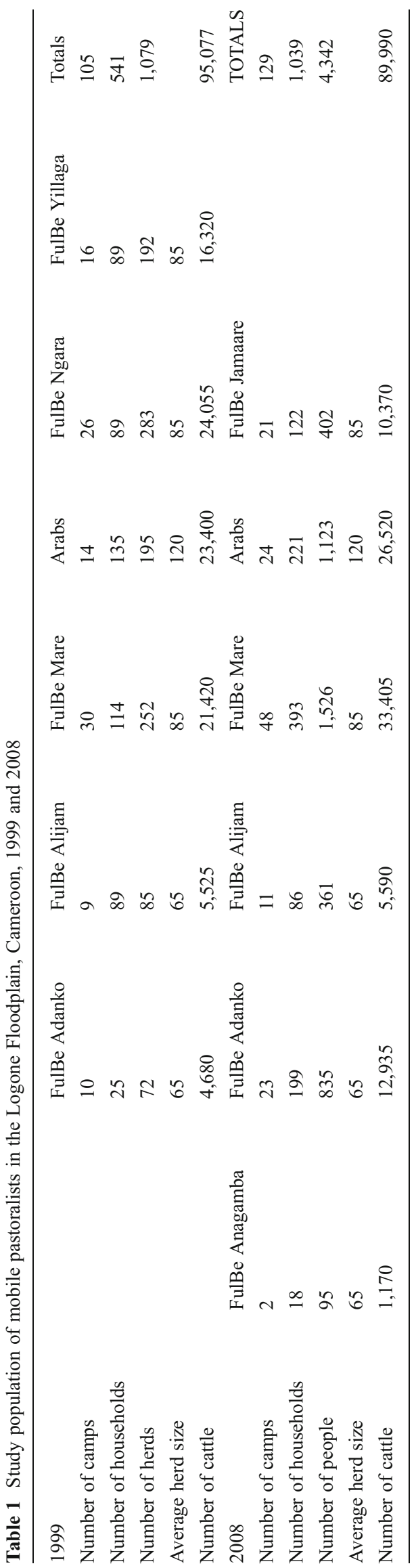


Fig. 1 Transhumance orbits in the Far North Region of Cameroon

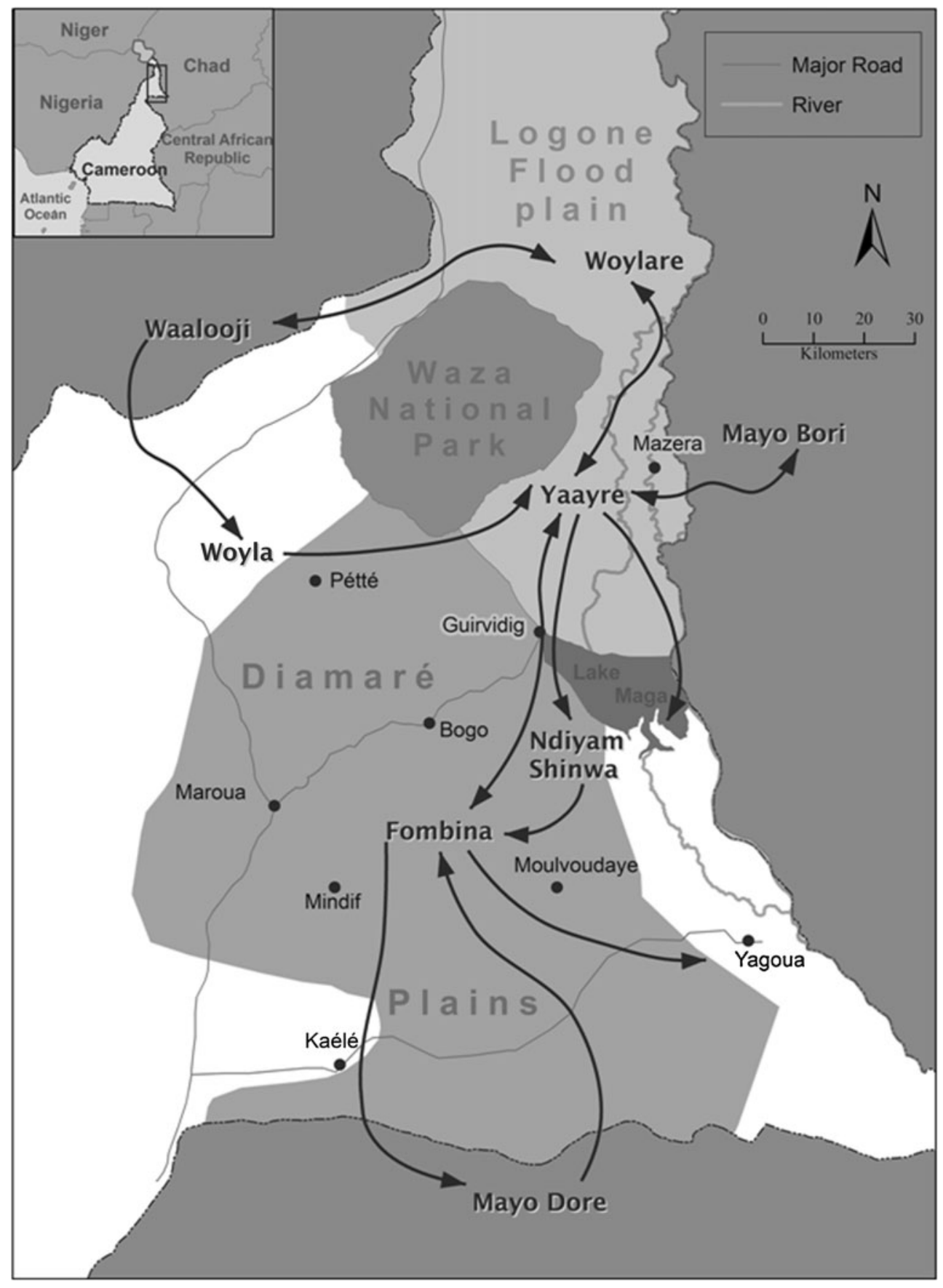

in June, while others move south to the grazing lands that surround Lake Maga. Pastoralists find nutritious regrowth and surface water in the floodplain far into the dry season, when surrounding pastures have dried up. At the start of the rainy season, pastoralists return to the higher elevated dunes of the Diamare or their respective countries.

The vegetation in the floodplain is relatively homogenous in terms of forage quantity and quality because of the extreme flatness of the area resulting in only limited variation in flooding depth and duration (Scholte 2007). There is a weak coupling between herbivores and vegetation as the predominantly perennial vegetation is controlled by flooding depth and duration and naturally protected against overgrazing because up to two-thirds of the biomass is stored underground. In addition above ground biomass is generally inaccessible to livestock during the flooding for 6 months of the year (Scholte 2007).

Our study area is a $1,000-\mathrm{km}^{2}$ section of the Logone Floodplain with well-defined boundaries of the Waza National Park in the west, the Logone River in the east, the irrigated rice fields of SEMRY in the south, and the village of Zina in the north. The research site overlaps with 
the pilot zone of the Waza Logone Project (1990-2003), which started reflooding of the pilot zone by opening an old waterway in the dike along the Logone River in 1994 (Scholte 2005).

Like other African floodplains, such as the Inner Niger Delta (Mali), the Sudd (Sudan) and the Kafue flats (Zambia), the Logone floodplain is an important and complex socio-ecological system in terms of biodiversity and livelihoods for local populations. The floodplain is used by multiple ethnic groups which make a living in different economic activities, including fishery (Kotoko, Musgum), agriculture (Musgum), and pastoralism (Arab, FulBe, Musgum). These systems use multiple-use common-pool resources and the resulting management systems are complex (Haller 2010).

Here we focus on mobile pastoralists who are permanently on transhumance and use our study area in the Logone Floodplain at some point during the dry season. This category comprises approximately 1,000 households of mobile pastoralists divided over approximately 130 camps and includes Suwa Arabs and FulBe, sub-divided into Jamaare, Mare, Alijam, Adanko, and Anagamba (Table 1). These different FulBe groups are endogamous and have their own dialect, cattle breed, houses, and marriage system. The number of households and camps changes continually through the year and over the years as households leave one camp to join another and/or leave the study area or Cameroon altogether.

\section{A Case Study of Management of Open Access}

Management of open access may not be as paradoxical as the literature on common property regimes suggests (Feeny et al. 1990; Lane 1998; McCay and Acheson 1987; Ostrom 1990; Peters 1994). Open access has been contrasted with common property regimes, which are managed by an identifiable community of interdependent users who can exclude outsiders and regulate use by members (McCay and Acheson 1987; Ostrom 1990). However, the first longitudinal study of mobile pastoralists we conducted in the Logone Floodplain suggested that open access is managed (Scholte et al. 2006). The study focused on a $400-\mathrm{km}^{2}$ section of the floodplain that overlapped with the pilot zone of the Waza Logone Project (1990-2003), which started reflooding of the pilot zone by opening an old waterway in the embankment along the Logone River in 1994 (Scholte 2005). This led to changes in vegetation and transhumance patterns of mobile pastoralists, which we documented in five different years between 1993 and 1999 (Scholte et al. 2006). Vegetation has shown a steady increase in cover of perennial grass species (from 41 to $75 \%$ ) whereas no increase in invading plant species has been observed between 1993 and 2003 (Scholte 2005; Scholte et al. 2000). Grass productivity increased with the increasing above-ground biomass due to increased flooding as measured in 1994-1996 (Scholte 2007). Moreover, we found evidence that changes in grazing pressure matched changes in the available biomass in the floodplain.

Below we describe this self-organizing system of management of open access in which pastoralists redistribute themselves over the available grazing resources within and outside the floodplain.

\section{An Ethos of Open Access}

Mobile pastoralists in the Logone Floodplain share a strong ethos of open access to common-pool grazing resources. They believe that every pastoralist has the same rights to use grazing lands, regardless of ethnicity, nationality, seniority, or socioeconomic status. Pastoralists emphatically argue that access is free and open for everyone. When asked about open access, pastoralists would say, na'i non, naa yimBe "it's [about] cattle, not [about] people", or nagge nyaamataa nagge "cattle do not eat [other] cattle," meaning all cattle are equal and have equal access to the pastures.

For mobile pastoralists, keeping cattle is not only a way of making a living and a way of life. One could argue that cattle are life because without them people cannot live as pastoralists. In this sense, to deny cattle access to grazing resources is to deny pastoralists life. This ethos of open access, which is shared among all mobile pastoralists in our study area, including absentee owners and their hired herders, informs how pastoralists coordinate their movements and use of common-pool grazing resources.

Customary Rights Over Campsites do not Regulate Access to Resources

When asked about their transhumance movements, pastoralists gave us the locations were they stayed, (hoodaande, pl. koodaande,). The settlements, which we refer to as camps, consist of multiple tents that are either lined up south to north facing west towards the herds (e.g., FulBe Mare) or in a circle with a diameter of about 250 to $400 \mathrm{~m}$ with the herds in the middle (e.g., Arabs). In the Logone Floodplain, camps are often located in depressions (coofol, pl. coofi) for easy access to water for humans and calves and protection from bush fires. Pastoralists may stay in some koodaande an extended period (sojourn), up to 4 months, while they stay in others for only a few days (transit). Different pastoralists may use the same hoodaande either for transit or sojourn.

However, hoodaande also refers to a larger area that incorporates multiple campsites. When taking GPS coordinates, we found that multiple camps give the same toponym for their hoodaande. Thus a hoodaande can refer to a 
campsite but also a camp zone, i.e., an area with multiple campsites.

Mobile pastoralists regularly return to the same campsite and put their tents in exactly the same location as the previous year. Pastoralists gain customary rights over campsites after 2 or 3 years of consecutive occupation in a particular season, after which people start referring to the campsite as hoodaande wayne or the campsite of so-and-so, even if the campsite was earlier used by someone else for as long as 20 years. The customary rights concern only the locations of the tents and the corrals, but not the surrounding grazing resources or other potential campsites in the camp zone. When pastoralists vacate a campsite they do not so much retain the right to occupy the site, but the right to be asked for 2 of 3 years (see also Myers 1982). Pastoralists can tell whether a site has been vacated or not, but they will also check with other pastoralists. Information about pastoralists' occupation of campsites is widely known and shared; everyone knows where everyone camps within an area. In fact, the location of camps is usually the first topic of discussion among mobile pastoralists after extended greetings.

Customary rights over campsites do not give pastoralists exclusive access over the common-pool grazing resources surrounding the campsite. Moreover, the grazing radii of multiple campsites overlap (e.g., the herds in Lugge Banana share pastures with those from the camp zones of BaDDiwol, Kazre, Yadaka, and Cubuna) (Fig. 2) as the average grazing radius in the dry season is $4.5 \mathrm{~km}$ (Moritz et al. 2010). There is also no de facto regulation of access to common-pool grazing resources through controlled access to water as among the Turkana (McCabe 1990) or the Gabra (Robinson 2009). In the floodplain most watering places are natural-rivers, ponds, depressions, lakes-and located throughout the floodplain, while the artificial lakes dug by the Lake Chad Basin Commission are explicitly open for all pastoralists from the member states (Cameroon, Chad, Niger, and Nigeria).

Pastoralists can set up camp wherever and whenever they want. Thus, access to camp zones is open, even when specific groups have customary rights to campsites within these zones. No one is obliged to ask for permission from traditional or governmental authorities or other pastoralists to set up camp in the zones or near established campsites. This applies to all pastoralists, including newcomers from other groups or countries. Pastoralists may ask fellow pastoralists whether they can set up camp close by but permission cannot be refused. Moreover, many pastoralists do not ask on principle ("pastoralists never ask" explained one of our informants) or inform their neighbors about site decisions even when they set up camp $250 \mathrm{~m}$ from another campsite. These rules are not limited to the floodplain; they also apply to the rainy season grazing areas in the Diamaré.

Some pastoralists expressed frustration that others set up camp so close to them, but no one argued that they have exclusive access. If they are not content, they can only move. Sometimes conflicts arise when pastoralists try to chase away others by "accidently" sending their herds through the other camp. But everyone knows, even those using this strategy, that this is not allowed and in violation of the ethos of open access. We came across very few conflicts among pastoralists over campsites and in all the ethos of open access was reaffirmed as everyone discussed the violation. There is no formal system for punishment of violators, but the reputation of pastoralists denying open access to others is affected. In a sense, management of open access is not an oxymoron because there are clear rules about who has access to the common-pool grazing resources (all pastoralists) and who can be excluded (no one). The rules are reaffirmed in everyday practice and are meaningful to mobile pastoralists-without access to common-pool grazing resources they cannot survive in this semi-arid environment.

\section{How Pastoralists Distribute Themselves Over Available} Resources

Mobile pastoralists in the region use opportunistic grazing strategies that closely track resources and are highly appropriate and effective ways to cope with the variable, unpredictable, and heterogeneous environments of Africa's drylands (Behnke and Scoones 1993). Mobile pastoralists in the Far North Region are either moving or thinking about moving. They are continuously assessing the state of their grazing areas by monitoring the condition of their animals and will move to wherever they think their animals will do better.

The general transhumance pattern of mobile pastoralists in our study is as follows. In the rainy season (duumol), July-August, most mobile pastoralists camp in the MindifMoulvoudaye or the Pétté areas (Fig. 1). Within a week of the end of the rains in September-October, they move en masse to the Logone floodplain using existing transhumance routes. In the cold dry season (dabbunde), NovemberJanuary, most mobile pastoralists are in the southern floodplain. They divide their herds and send the strongest animals on a separate transhumance (luci) with young herders. In the hot dry season (ceedu), February-May, most of them move either further north in the floodplain or south to the shores of Lake Maga. At the beginning of the rainy season (seeto), June, they leave the floodplain and follow the clouds to wherever rains have fallen and fresh forage can be found.

There is considerable spatiotemporal variation in this transhumance pattern due to the complex decision-making process in which multiple factors are considered simultaneously for each individual move, including proximity to markets, marriage arrangements with other camps, health of household members, risk of attacks by cattle thieves (see also Drent 2005; McCabe 2004). Nevertheless, there is considerable regularity in the transhumance patterns at 
Fig. 2 Campsites and zones in a section of the Logone floodplain, February 2009

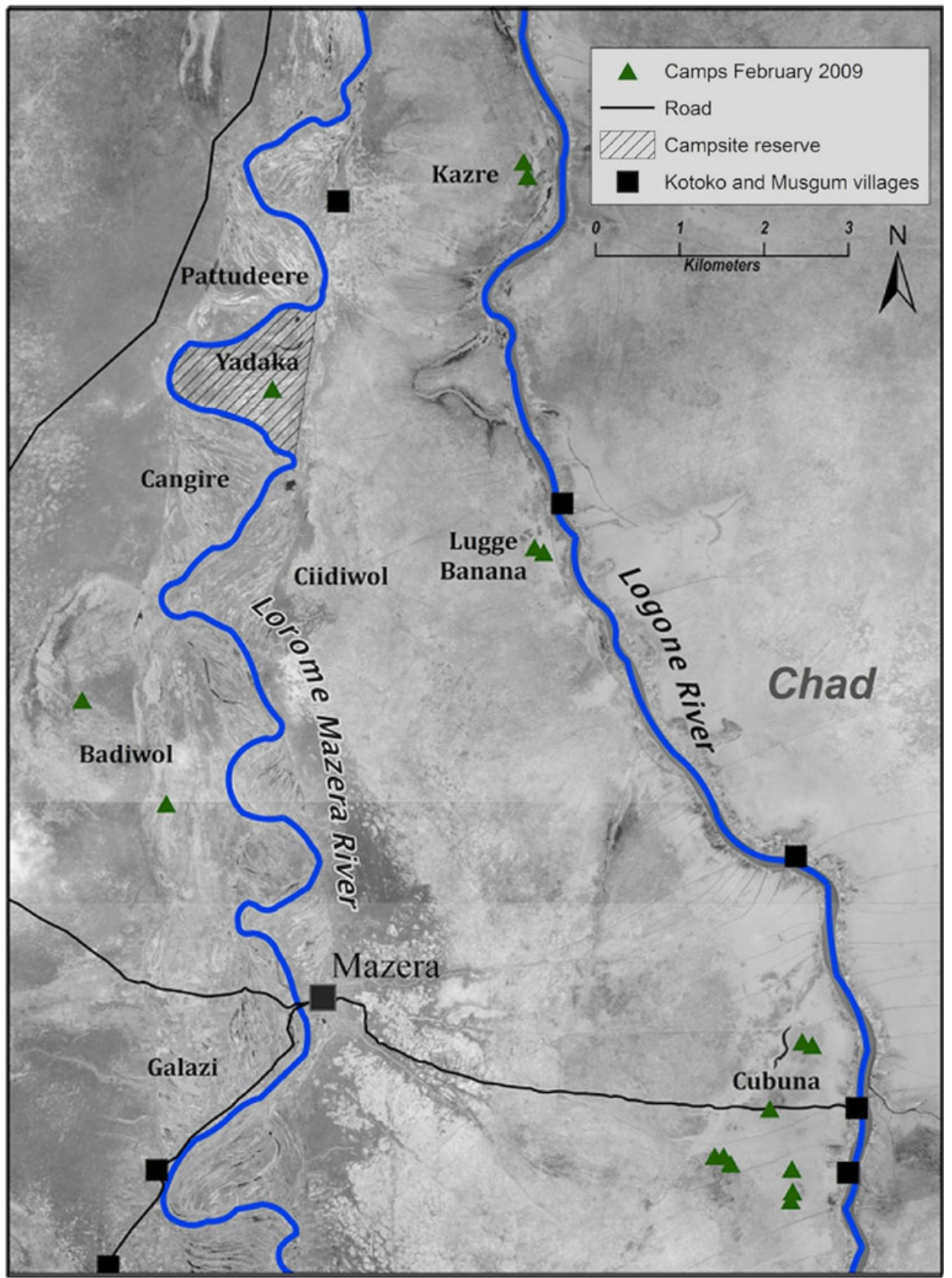

population level, which is the result of the habitual movements of the herds in which animals develop woowaande (habitude) or preference for the pastures and campsites they visit annually and where they were born and/or gave birth.

Pastoralists follow regular transhumance orbits in which they use established transhumance routes or corridors that connect their seasonal grazing areas. However, these transhumance orbits are subject to continuous change. Stenning has described how this happens through processes of migratory drift (eggol), "the gradual displacement of transhumance orbits," and migration (perol), "the assumption of new transhumance orbits by a sudden and often lengthy movement" (1957). Pastoralists adjust their orbits to the "normal" spatiotemporal variation in forage availability due to variation in rainfall patterns by changing the timing of their movements from one area to another, e.g., the rainy season area (ruumirde) to the cold dry season area (dabbirde) or by moving to nearby campsites within one area. The result is a pattern of continuity and change, in which small changes from year to year cumulatively lead to significant changes in transhumance patterns over time. However, when confronted with major changes in forage availability like droughts or security threats, pastoralist may radically change their regular transhumance orbits. For example, many mobile pastoralists changed 
their transhumance orbits during the 1973-1974 droughts. Instead of an annual transhumance from Waalooji in Nigeria (rainy season) to the Yaayre (dry season), pastoralists moved between Fombina (rainy season) and the Yaayre (dry season) (Fig. 1). Similarly, the 1984-1985 drought sent some pastoralists further south to Chad, where they orbited between Fombina (rainy season) and Mayo Dore (dry season). While most returned to the Yaayre after the drought in 1986, others stayed in Chad. More recently, some of these pastoralists in Mayo Dore returned to Cameroon due to insecurity in Chad. Recently, in 2009-2010, a number of mobile pastoralists changed their transhumance orbits because of a deteriorating security situation in which they tried to avoid areas where criminal gangs kidnapped pastoralists' children for ransom (Moritz and Scholte 2011).

Stenning (1957) notes that FulBe pastoralists do not flee to areas they do not know; they have either been there before (i.e., a previous transhumance orbit) or they know people who are there now (see also Bassett and Turner 2007). We see the same pattern in the Logone Floodplain. Through processes of migratory drift and migration, mobile pastoralists have created extensive networks of friends and family across the Chad Basin. Because pastoralists are relatively independent and autonomous, they do not migrate en masse; there are always some households or camps that remain behind. In addition, marriages allow pastoralists to maintain and create relations with households and camps on other transhumance orbits. Because of these extensive networks, mobile pastoralists move with relative ease across borders within the Chad Basin. Pastoralists also redistribute themselves through changes in social organization as households frequently leave one camp to join another or two camps may join in one site and separate in the next. The result is a pastoral population in flux and an almost continuous redistribution of pastoralists within and beyond the floodplain; most pastoralists who currently use the floodplain only came in the last 40 years, while the FulBe Daneeji, who used the floodplain earlier, have all moved to Chad and the Central African Republic.

\section{Exceptions to the Rule}

Despite the strong ethos of open access among mobile pastoralists, there are a few reserves with exclusive access in the Logone Floodplain. We found two types: 1) grazing reserves for Musgum agro-pastoralists and 2) campsite reserves for mobile pastoralists. The Musgum, who are permanent inhabitants of the floodplain since the late 1800s (Seignobos and Jamin 2003), play a critical and direct role in the development of both types of reserves. The campsite reserves of the mobile pastoralists are relatively small-less than 25 ha-and the Musgum grazing reserves are even smaller (Fig. 2).

The Musgum live year-round in the floodplain and practice fishery, agriculture and animal husbandry. They own approximately 2,500 or $2.5 \%$ of the cattle that use the study area in the dry season. Most Musgum own only a few cattle and pool their animals in village herds that are either watched by a hired herder or roam around the village without supervision. During flooding, Musgum keep their animals in stables or send them with mobile pastoralists. They no longer send their animals on transhumance in the dry season as in the past and this is one of the reasons why some villages have declared certain zones as grazing reserves (surande) and many Musgum do not share the ethos of open access. To a certain extent the reserves are symbolic because they are small, located next to the village, and herds graze primarily outside the reserve. Mobile pastoralists understand why Musgum want the reserves, but they note that the bush is for all and assert the ethos of open access by letting their cattle graze in the reserves, a source of constant tension between the two groups.

There are two campsite reserves in the study area that are used by mobile pastoralists: Duunde (literally island) and Yadaka (name of the neighboring Musgum village). The Musgum chief of the village Gala claims exclusive rights over Duunde, a small island that was previously part of Chad, and struck deals with two Jamaare'en absentee owners whose hired herders set up camps on the island. The absentee owners told us that they pay the chief for the right to set up camp on the island and not for exclusive grazing rights, even though this is what they de facto get. Yadaka is a campsite used by the same three Jamaare'en households for the last 14 years, but where other pastoralists have been "chased away" by Musgum villagers. In both cases Musgum chiefs played an active role in the creation of the reserves. Both the pastoralists that have exclusive access and the ones that are excluded state that "pastoralists never exclude pastoralists" but blame the Musgum for the exclusion. In both cases, the exclusive access concerns campsites, not the common-pool grazing resources surrounding the sites.

The shift in livestock ownership from subsistence pastoralists to absentee herd owners and the increase in herding contracts has been held responsible for negative effects on rangeland management (Homewood 2008). However, there is no evidence that this is the case in the Logone floodplain, where approximately $35 \%$ of the herds are under contract. Only two absentee owners have exclusive access to campsites (but not grazing resources); the great majority of absentee owners does not. Moreover, all mobile pastoralists, including absentee owners and hired herders, profess a strong commitment to the ethos of open access to common-pool grazing resources.

\section{Regulation Through Taxation?}

There is ample evidence for open access among mobile pastoralists, but can access to common-pool grazing resources be regulated through taxation by traditional and 
governmental authorities (Fokou 2010)? We think that the payment of taxes does not regulate access to common-pool grazing resources. Pastoralists pay a transhumance tax, which is collected in each municipality that pastoralists camp in and ranges from about 10,000 FCFA (\$20) to 12,000 FCFA (\$24) per herd. On average pastoralists stay in three municipalities per year, resulting in 30,000 FCFA (\$60) in transhumance tax, which seems high and pastoralists do complain. However, using conservative estimates of a herd of 50 cattle with an average value of 100,000 FCFA (\$200) per animal the annual transhumance tax amounts to $0.6 \%$ of their value and only $3 \%$ of pastoralists' annual income from cattle sales. There is no indication that taxes regulate access, even for poorer pastoralists.

Previously, we wrote that pastoralists announce their presence in the territory by paying a visit to the traditional authorities (Moritz et al. 2002). Now we know that pastoralists simply set up camp wherever they want because sooner rather than later the authorities will show up to collect the transhumance tax. Leaders of sub-ethnic groups may visit the traditional authorities and pay tribute, but they do this to solidify their political position within their community rather than to gain access to common-pool grazing resources. The leaders of pastoral groups we interviewed referred to the payments to traditional authorities as ceede $h u D O$ (literally money for grass) and ceede sabur (literally money for soap), which suggests that it is a small token gift rather than a tribute. More importantly, we found both in the 1990s and from 2008 to 2010 that no one is refused access, including a few pastoralists who explicitly refused to pay even a nominal amount to a chief they considered a crook. There is no evidence of regulation through taxation.

Moreover, the official national policy is that access to common-pool grazing resources is open to anyone provided the animals are vaccinated and the transhumance tax is paid. When asked about the role of the authorities in regulating access, one pastoralist responded: Yamataa, kaDataa "[we] don't ask, [and we are] not refused [access]".

\section{Historical and Institutional Context}

The system of open access to common-pool grazing resources is not a recent phenomenon in the Logone Floodplain. Until the beginning of the twentieth century, the floodplain was a site of endemic insecurity that prevented FulBe pastoralists from using it (Seignobos and Jamin 2003). Nineteenth and early twentieth century European travelers (Barth 1965) described an area that was ravaged by war between pre-colonial polities of Kanuri and FulBe and Musgum and other ethnic groups (Bauer 2002). However, colonial pacification in the 1920s opened up the area for pastoralists (Delclaux et al. 2010), and by the 1960 s, pastoralists from all over the Diamaré went on transhumance to the study area (Mouchet
1960). Although there are no good descriptions of pastoral systems in the Logone Floodplain before the 1980s, the accounts of Mouchet (1960) and our informants suggest that there has for a long time been open access to common-pool grazing resources in the Logone Floodplain.

The notion of open access to common-pool grazing resources is also not limited to mobile pastoralists in the Logone Floodplain; national laws and international agreements support it. It is a good example of nested institutions in which the management system of mobile pastoralists is supported by higher institutions (Ostrom 1990; Ostrom et al. 2002). Rangelands in the Logone Floodplain and the Far North Region are legally state property (Ordinance No. 74-1 of 1974). However, the law explicitly gives all pastoralists the right to use these common-pool resources unless the state uses these grazing lands for other purposes such as wildlife conservation or agricultural development projects. National laws thus support pastoral mobility and the system of open access to grazing lands.

In addition, the Lake Chad Basin Commission has been supporting the system of open access to common-pool grazing resources since the 1960s, when it was created by the four countries bordering Lake Chad: Cameroon, Chad, Niger, and Nigeria. The aims of the commission are to regulate and control the use of water and other natural resources in the basin and to initiate, promote, and coordinate natural resource development projects and research. International agreements between Lake Chad Basin Commission member countries and more recently the Central African Republic and Sudan enable freedom of movement for pastoralists in the Chad Basin provided they have vaccinated their animals and paid the local and national taxes.

\section{Discussion}

Our case study raises two main questions. First, how representative is this system of open access for other pastoralists in West and Central Africa? We found indications that the system we describe for the Far North Region is common in other pastoral systems in West Africa, even when it is not labeled as such (Frantz 1986; Horowitz 1986; Stenning 1957; Swallow 1990) and it has also been described for pastoralists outside Africa (Bradburd 1992). It is also not limited to FulBe pastoralists; Arab pastoralists, who originally came from the Sudan and migrated westwards to the Chad Basin in the last centuries, share the ethos of open access. However, not all pastoral systems in the Chad Basin or West Africa have open access, e.g., the Toubou and Arabs in central Chad repeatedly clash over the ownership of wells and thereby access to grazing land.

Second, there are several theoretical implications of this case study. First, we are not only dealing with open access, 
but also with an open system in which there are no social or natural boundaries, and this has implications for our understanding of pastoral systems and management of commonpool resources. Second, we think that the concept of the ideal free distribution, in which grazing pressure matches available resources, is useful to evaluate the effectiveness of this management system. Finally, our case study may serve as a model of a self-organizing management system of common-pool resources for other resource systems.

\section{An Open System}

FulBe pastoralists in the Far North Region say that they are like birds (FulBe bana colli)-not tied to any place they can go wherever they want and whenever they want. They have no territories, homelands or home ranges and they live interspersed with different groups of pastoralists and agriculturalists. The distribution of Fulfulde speakers in subSaharan Africa underscores the notion that their pastoral system is truly open system (Fig. 3). Originally from the Senegambia region, FulBe pastoralists have gradually moved eastwards to Sudan and Ethiopia, northwards into the Sahel, and southwards into the sub-humid zone.

The continuously changing distribution of FulBe pastoralists across sub-Saharan Africa underscores that we are dealing with an open system. What seems stable and bounded at low spatiotemporal scales-the annual transhumance orbit-is highly dynamic and unbounded when the spatiotemporal scale is expanded. Stenning (1957) explained how small changes in the annual transhumance lead to considerable changes over time. However, we have tended to "box" mobile pastoralists in study areas and freeze their annual migrations in the ethnographic present. We have not made the conceptual leap to describe and understand mobile pastoral systems as open systems because our theoretical models assume that resources are bounded and limited. But these imagined boundaries disappear when pastoral systems are analyzed at larger spatiotemporal scales. When pastoral mobility is examined in a historical perspective at temporal scales of decades and centuries and at spatial scales beyond regions and nations, common-pool grazing resources are, for practical purposes, unbounded and unlimited.

The migrations of FulBe pastoralists over the last centuries show that there are no real boundaries. Pastoralists may be harassed at international borders, but this does not prevent them from crossing them. Political change often offered opportunities: the nineteenth century FulBe Jihads and the colonial "pacification" opened up new grazing lands across West Africa (Seignobos and Iyébi-Mandjek 2000), just as recent political turmoil and insecurity in Chad, the Central African Republic and the Jos Plateau in Nigeria closed off grazing lands. There are also no apparent ecological boundaries that inhibit their expansion. FulBe pastoralists have moved north in the Sahel, entering grazing lands that were traditionally used by Tuareg, Tubu and Arab pastoralists (Bonfiglioli 1988), and further south into sub-humid zones by adapting their breeding strategies (Bassett and Turner 2007). FulBe pastoralists continue to move and exploit new ecological niches (Boutrais 1996).

Pastoralists in East Africa are also continuously on the move and their territories have changed over time and continue to change despite being circumscribed by other pastoral groups (Schlee 2010), but at smaller spatial scales and longer temporal scales than in West Africa, where pastoralists move across multiple countries into different

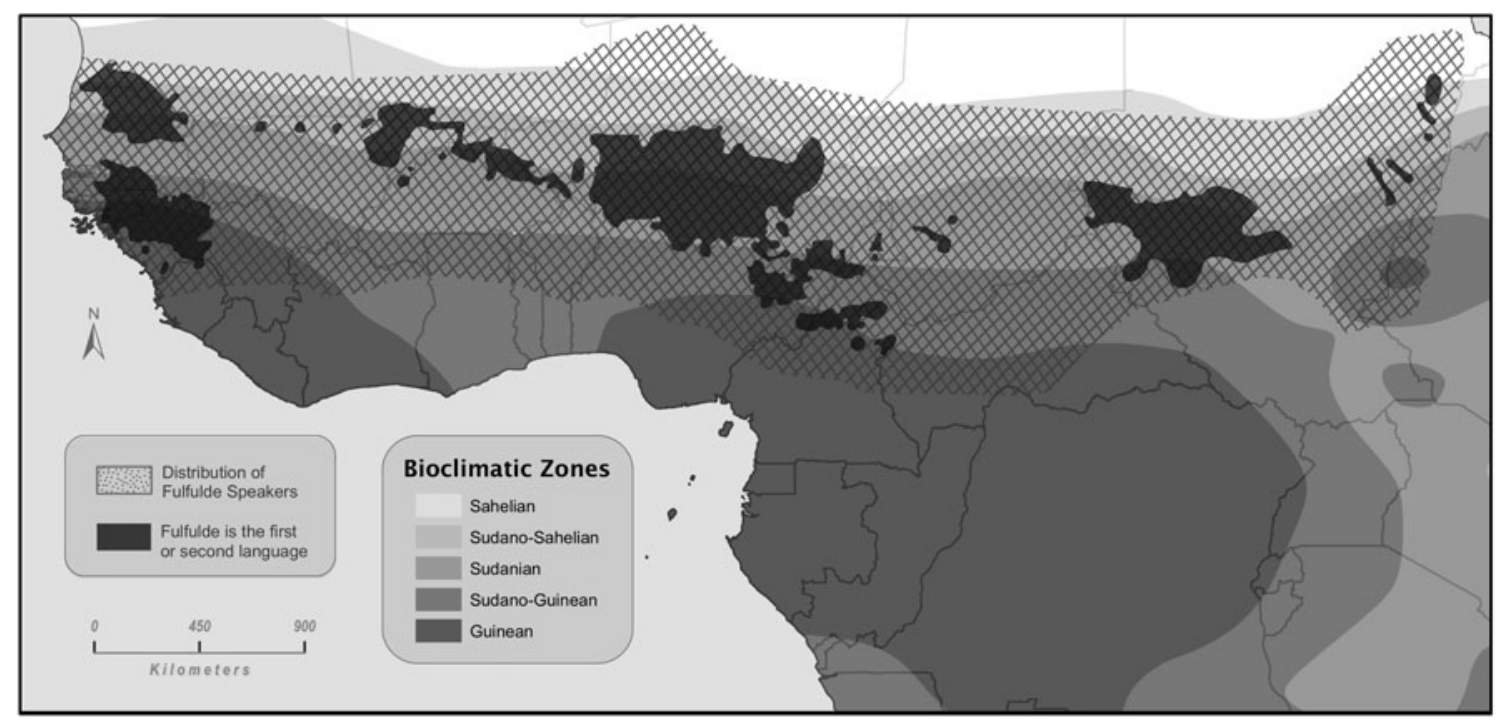

Fig. 3 Distribution of Fulfulde speakers in sub-Saharan Africa. Caption: Bioclimatic zones are derived from rainfall data from Nicholson et al. (1988), classifications from Bassett and Turner (2007), and the distribution of Fulfulde speakers from Boutrais (1996) 
ecological zones within decades (Boutrais 1996). There may be a number of reasons for the differences between the two regions: geographic orientation, bioclimatic conditions, and a religion that transcends local groups. The east-west orientation of West Africa facilitates the eastward spread of FulBe pastoralists across the Sahelian and Sudano-sahelian climatic zone as they could migrate over great distances within one bioclimatic zone. In East Africa, on the other hand, pastoralists are circumscribed by different climatic and ecological zones that were associated with tsetse flies and sleeping sickness (Gifford-Gonzalez 2000). Bioclimatic conditions may also have contributed to a greater mobility of FulBe pastoralists in West Africa. Whereas West Africa is characterized by a monomodal rainfall pattern, the Greater Horn of Africa has a bimodal rainfall pattern and greater inter-annual variability in rainfall (Ellis and Galvin 1994). Consequently, West African pastoralists make longer transhumance movements to exploit the more predictable spatiotemporal rainfall patterns, whereas pastoralists in the Horn of Africa make much shorter nomadic movements to exploit less predictable spatio-temporal variability in rainfall patterns (Ellis and Galvin 1994). The practice of long-distance transhumance facilitates the migrations to new areas, as West African pastoralists have the habit of opportunistically seeking new grazing lands (Bassett and Turner 2007). Islam has further integrated West African pastoralists in a wider society that included villages, towns, and cities. The umma, or Muslim community, transcends the diversity of pastoral and non-pastoral populations and facilitated the pastoral migrations to new areas. Islamic jihads have also facilitated the spread of FulBe pastoralists and provided more security in areas that were previously inaccessible.

In addition, the pastoral system in the Far North Region is also an open system in the sense that there are no strong social boundaries. All who are committed to mobile pastoralism, in which the needs of animals are central, are members of the user group. And while there are distinct ethnic groups among pastoralists, these groups are not territorial, and the ethnic boundaries are permeable as people "enter" ethnic groups that they share transhumance routes with (see also Bradburd 1992).

\section{An Ideal Free Distribution of Mobile Pastoralists?}

The mechanisms of decision-making described here, as well as the finding that grazing pressure tracked productivity at the scale of the floodplain as a whole are reminiscent of the predictions of negative density-dependent habitat selection models, such as the Ideal Free Distribution (IFD) (Fretwell and Lucas 1969; Hamilton 2010). Negative densitydependence results when the suitability of a habitat declines with increasing density of competitors on that patch. The dynamics of resources on the floodplain are characterized by accumulation of resources during the rainy and flooding season and gradual decline of these resources through desiccation and grazing in the dry season. This pattern conforms to that assumed in 'depletion' models of the IFD (Sutherland 1996). Depletion models predict the spatiotemporal sequence and timing of patch exploitation, starting with use of highest quality patches early in the season and successively adding initially poorer patches as the quality of better patches declines through grazing (Sutherland 1996). Use of low quality patches will also depend on overall density, with increasing use of low-quality patches when density is high (Mobaek et al. 2009). Thus, in depletion models, the population response to increasing consumer:resource ratio in any given patch is to increase the number of patches used.

Ideal free models do not necessarily alleviate the Tragedy of the Commons. Indeed, depletion may become severe over the whole landscape as even very poor patches become occupied (Sutherland 1996). However, we argue that 1) because pastoralists live in an open system in which they can move freely into and out of the Logone Floodplain as well as within the floodplain, the number of available patches becomes very large at large spatial scales and 2) the spatiotemporal patterns of resource depletion and renewal, in which depleted patches are renewed and the spatial distribution of herders on the floodplain reset by the onset of the rainy season and flooding, full occupancy and severe depletion of all patches in the limited time of the dry season is unlikely. In other words, we expect that over a wide range of conditions, individuals can do better by moving rather than by increasing intensity of exploitation in a given patch.

We argue that the ideal free distribution, and, in particular, the depletion model, is a useful concept to describe the distribution of pastoralists in the floodplain. However, we do not argue that pastoralists will meet the quantitative predictions of any existing ideal free models. The pastoral system does not fit several of the assumptions of ideal free distribution models. In particular, travel times between habitats are non-negligible, cattle and herders are organized hierarchically into herds and camps, so that movement decisions of individual cattle and individual herders are not independent of those of other cattle and other herders, and regularity of transhumance routes limits the patches used by any single herder. Ideal free distribution models also assume perfect information of the relative quality of patches. While herders do not have perfect information, we assert that they are likely to have complete information, i.e., sufficient knowledge to predict with a certain probability the patch conditions, instead of perfect information, i.e., knowing the exact patch conditions (Kelly 1995).

The question is whether the ideal free distribution is the epiphenomenal consequence (Hunn 1982) of high mobility, low population density, and annual flooding, as Ruttan and Mulder (1999) suggest is the case in some East African pastoral systems, or whether there is management of common-pool resources in the floodplain. And if there is a 
management system, as we argue below, can we identify causal links that are responsible for the emergence of an ideal free distribution of mobile pastoralists in the floodplain?

\section{A Model of a Self-Organizing Management System}

The openness of the pastoral management system in the Logone Floodplain does not mean that we cannot describe and analyze it using the theoretical framework of the commons. Since Ostrom (1990) published eight design principles for successful commons, more critical variables have been identified (Agrawal 2002). The challenge has been to develop general mechanisms that explain which sets of causal configurations of variables lead to successful management of common-pool resources (Poteete et al. 2010). Reviewing major comparative studies of the commons, Agrawal (2002) identified critical variables and proposed several causal mechanisms for successful commons. When we compare our case study of mobile pastoralists in the
Logone Floodplain with Agrawal's list of critical variables (Table 2), there are two clear patterns. First, there is no good match in terms of the characteristics of the social and ecological systems, primarily because both systems are not bounded. Second, there is a good match in terms of relationships between resource system, users, and governance system. In short, the social and ecological systems of mobile pastoralists in the Chad Basin are quite different from those that are normally associated with successful management of common-pool resources. However, the social and governance systems of mobile pastoralists are well adapted to the resource system in the Chad Basin.

The question remains as to what combination of variables is most critical for the management of open access in the Chad Basin. Following Agrawal's (2002) analytical approach, we have identified two causal links in which the first produces an ideal-free type distribution and the second results in sustainable exploitation of common-pool resources.

Density-dependent distribution $=\mathrm{f}$ (spatiotemporal variation of renewable common-pool resources, open access,

freedom of movement, networks across nations, complete information,

independent decisions, habitude)

The first function describes how pastoralists distribute themselves in relation to common-pool grazing resources. We expect to find an ideal-free type distribution when mobile users with complete information, freedom and ability to move within and across nations, and independent decision-making capabilities, have open access to depletable common-pool resources that are highly variable is space and time. Such a distribution will be resistant to strategies that overselect or overstay on certain patches, because the costs of overusing these patches fall most heavily on the individuals that overuse them (Hamilton 2010). However, it should be noted that it is not resistant to strategies that increase the rate of resource exploitation overall (see second function), nor is it resistant to increases in population were it not an open system.

Ecological sustainability $=\mathrm{f}($ subsistence economy, appropriate technology, low external investments $)$

This second function describes how pastoralists exploit common-pool grazing resources in the open system described above. We expect ecological sustainability when it is primarily a subsistence system with appropriate technology and low external capital investments.

\section{Open Access as a Management System or Property Regime}

We argue that open access is not just the epiphenomenal consequence of high mobility, low population density, or the absence of a private, state, or common property regime. For example, evolutionary models suggest that there is no reason to expect common property regimes when resources are unbounded and unlimited (Alvard 1998; Ruttan and Mulder 1999) as is the case in the open system of mobile pastoralists in the Chad Basin that we have described here. However, we argue that this system of open access can be described as a management system or property regime and not just as the absence of a property regime. Pastoralists are committed 
we see it even when pastoralists tell us that it is open access. The reluctance to describe a situation as open access is understandable because of its negative associations with tragedy of the commons. Hardin (1968) wrote that "freedom in a commons brings ruin to all" but in the Chad Basin where grazing resources are highly variable in space and time, it is critical that mobile pastoralists have freedom of movement and open access to avoid ruin to common-pool resources. The conditions that we identified as being critical for this self-organizing management system of common-pool resources with open access-mobile users, shared information, freedom of movement, autonomous decision-making, and open access to depletable common-pool resources that are highly variable in space and time-may also be met and thus be relevant for other resource systems, including fisheries.

Acknowledgments This research has been supported by the National Science Foundation (BCS-0748594), the National Geographic Society (8306-07), and the Division of Social and Behavioral Sciences and the Anthropology Department at the Ohio State University. We want to thank the Ministry of Scientific Research and Innovation (MINRESI), the Ecole de Faune de Garoua, and the University of Maroua for granting research permission and research affiliation. Paul Maddock and Qian Hao made the maps, Kristen Ritchey conducted structured interviews in 2009, and CARPA research assistants Oumarou Kari, Haman Wabi, and Sali Siddiki collected much of the spatial data. We would like to thank Monique Borgerhoff Mulder, Endre Nyerges, and the reviewers for critical comments on earlier versions of this article.

\section{References}

Agrawal, A. (2002). Common resources and institutional stability. In Ostrom, E., Dietz, T., Dolsak, N., Stern, P. C., Stonich, S., and Weber, E. U. (eds.), The Drama of the Commons. National Academy Press, Washington, D.C., pp. 41-85.

Alvard, M. S. (1998). Evolutionary Ecology and Resource Conservation. Evolutionary Anthropology 7: 62-74.

Barth, H. (1965). Travels and Discoveries in North and Central Africa: Being a Journal of an Expedition Undertaken Under the Auspices of H.B.M.'s Government in the Years 1849-1855. Vol. I, II, and III. Frank Cass, London.

Bassett, T. J., and Turner, M. D. (2007). Sudden Shift or Migratory Drift? Fulbe Herd Movements to the Sudano-Guinean Region of West Africa. Human Ecology 35: 33-49.

Bauer, F. (2002). L'expédition Allemande Niger-Bénoué-Lac Tchad (1902-1903). Karthala, Paris.

Behnke, R. H., and Scoones, I. (1993). Rethinking range ecology: implications for rangeland management in Africa. In Behnke Jr., R. H., Scoones, I., and Kerven, C. (eds.), Range Ecology at Disequilibrium: New Models of Natural Variability and Pastoral Adaptation in African Savannas. Overseas Development Institute, London, pp. 1-30.

Bonfiglioli, A. M. (1988). Dudal: Histoire de Famille et Histoire de Troupeau Chez un Groupe de Wodaabe du Niger. Production Pastorale et Société. Cambridge University Press \& Éditions de la Maison des Sciences de l'Homme, Cambridge.

Boutrais, J. (1996). Hautes Terres d'élevage au Cameroun. Vol. 1-3. Collection Études et Thèses. ORSTOM Éditions, Paris.
Bradburd, D. A. (1992). Territoriality and Iranian pastoralists: looking out from Kerman. In Casimir, M. J., and Rao, A. (eds.), Mobility and Territoriality: Social and Spatial Boundaries Among Foragers, Fishers, Pastoralists, and Peripatetics. Berg, New York, pp. 309-327.

Delclaux, F., Seignobos, C., Liénou, G., and Genthon, P. (2010). Water and people in the Yaere floodplain (North Cameroon). In Álvarez, M. A. (ed.), Floodplains: Physical Geography, Ecology and Societal Interactions. Nova publishers, Hauppauge (NY).

Dietz, T., Dolsak, N., Ostrom, E., and Stern, P. C. (2002). The drama of the commons. In Ostrom, E., Dietz, T., Dolsak, N., Stern, P. C., Stonich, S., and Weber, E. U. (eds.), The Drama of the Commons. National Academy Press, Washington, D.C., pp. 3-34.

Drent, A. K. (2005). Je suis venu pour partir... je pars parce que je suis venu (1): A Qualitative Study About Nomadic Mobility in the North of Cameroon. Thesis, Wageningen University.

Ellis, J., and Galvin, K. A. (1994). Climate Patterns and Land-Use Practices in the Dry Zones of Africa. BioScience 44: 340-349.

Ensminger, J., and Knight, J. (1997). Changing Social Norms: Common Property, Bridewealth and Clan Exogamy. Current Anthropology 18: 1-24.

Feeny, D., Berkes, F., McCay, B. J., and Acheson, J. M. (1990). The Tragedy of the Commons: 22 Years Later. Human Ecology 18: 81-103.

Fernández-Giménez, M. E., and Le Febre, S. (2006). Mobility in Pastoral Systems: Dynamic Flux or Downward Trend? International Journal of Sustainable Development \& World Ecology 13: 341-362.

Fokou, G. (2010). "Tax payments, democracy and rent seeking administrators: common-pool resource management, power relations and conflicts among the Kotoko, Musgum, Fulbe and Choa Arab in the Waza-Logone floodplain (North Cameroon)". In Haller, T. (ed.), Disputing the Floodplains: Institutional Change and the Politics of Resource Management in African Wetlands. Brill.

Frantz, C. (1986). Fulani continuity and change under five flags. In Adamu, M., and Kirk-Greene, A. H. M. (eds.), Pastoralists of the West African Savanna. Manchester University Press, Manchester (UK), pp. 16-39.

Fratkin, E., Galvin, K. A., and Roth, E. A. (eds.) (1994). African Pastoralist Systems: An Integrated Approach. Lynne Rienner publishers, Boulder (CO).

Fretwell, S. D., and Lucas, J. H. J. (1969). On Territorial Behavior and Other Factors Influencing Habitat Distribution in Birds. Acta Biotheoretica 19: 16-36.

Galaty, J. G. (1994). Rangeland tenure and pastoralism in Africa. In Fratkin, E., Galvin, K. A., and Roth, E. A. (eds.), African Pastoralists Systems: An Integrated Approach. Lynne Rienner Publishers, Boulder, CO, pp. 185-204.

Galvin, K. A. (2009). Transitions: Pastoralists Living with Change. Annual Review of Anthropology 38: 185-198.

Gifford-Gonzalez, D. (2000). Animal Disease Challenges to the Emergence of Pastoralism in Sub-Saharan Africa. African Archaeological Review 17: 95-139.

Goldschmidt, W. (1971). Independence as an Element in Pastoral Social Systems. Anthropological Quarterly 44: 132-142.

Haller, T. (ed.) (2010). Disputing the Floodplains: Institutional Change and the Politics of Resource Management in African Wetlands. African Social Studies Series. Brill, Leiden (Netherlands).

Hamilton, I. M. (2010). Foraging theory. In Westneat, D., and Fox, C. (eds.), Evolutionary Behavioral Ecology. Oxford University Press, Oxford (UK), pp. 177-193.

Hardin, G. (1968). The Tragedy of the Commons. Science 162: $1243-$ 1248.

Homewood, K. (2008). Ecology of African Pastoralist Societies. James Currey, Oxford (UK).

Horowitz, M. M. (1986). Ideology, policy, and praxis in pastoral livestock development. In Horowitz, M. M., and Painter, T. M. 
(eds.), Anthropology and Rural Development in West Africa. Westview Press, Boulder (CO), pp. 251-272.

Hunn, E. S. (1982). Mobility as a factor limiting resource use in the Columbian Plateau of North America. In Williams, N., and Hunn, E. (eds.), Resource Managers: North American and Australian Hunter-Gathers. Westview Press, Boulder, pp. 17-43.

Kelly, R. L. (1995). The Foraging Spectrum: Diversity in HunterGatherer Lifeways. Smithsonian Institution Press, Washington.

Lamprey, H. F. (1983). Pastoralism yesterday and today: the overgrazing problem. In Bourliere, F. (ed.), Ecosystems of the World 13: Tropical Savannas. Elsevier, Amsterdam, pp. 643-666.

Lane, C. (ed.) (1998). Custodians of the Commons: Pastoral Land Tenure in East and West Africa. Earthscan, London.

Legrosse, P. (1999). Les règles d'accès des troupeaux peuls aux pâturages du Delta central du Niger (Mali). In Niamir-Fuller, M. (ed.), Managing Mobility in African Rangelands. IT Publications, London, pp. 76-96.

McCabe, J. T. (1990). Turkana Pastoralism: A Case Against the Tragedy of the Commons. Human Ecology 18: 81-103.

McCabe, J. T. (2004). Cattle Bring Us to Our Enemies: Turkana Ecology, Politics, and Raiding in a Disequilibrium System. Michigan University Press, Ann Arbor (MI).

McCay, B. J. (2002). Emergence of institutions for the commons: contexts, situations and events. In Ostrom, E., Dietz, T., Dolsak, N., Stern, P. C., Stonich, S., and Weber, E. U. (eds.), The Drama of the Commons. National Academy Press, Washington, D.C., pp. $361-402$.

McCay, B. J., and Acheson, J. M. (1987). The Question of the Commons: The Culture and Ecology of Communal Resources. Arizona Studies in Human Ecology. University of Arizona Press, Tucson (AZ).

Mobaek, R., Mysterud, A., Egil Loe, L., Holand, Ø., and Austrheim, G. (2009). Density Dependent and Temporal Variability in Habitat Selection by a Large Herbivore; an Experimental Approach. Oikos 118: 209-218.

Moritz, M., and Scholte, P. (2011). Ethical Predicaments: Advocating Security for Mobile Pastoralists in Weak States. Anthropology Today 27: 12-17.

Moritz, M., Scholte, P., and Kari, S. (2002). The Demise of the Nomadic Contract: Arrangements and Rangelands Under Pressure in the Far North of Cameroon. Nomadic Peoples 6: 124-143.

Moritz, M., Soma, E., Scholte, P., Juran, T., Taylor, L., Kari, S., and Xiao, N. (2010). An Integrated Approach to Modeling Grazing Pressure in Pastoral Systems: The Case of the Logone Floodplain (Cameroon). Human Ecology 38: 775-789.

Mouchet, J. (1960). Enquête entomologique dans le Logone et Chari (13-25 mai 1960). I: Le Foyer de glossines du Logone et Chari. II: L'Anophélisme et les possibilités de lutte antipaludique. III: La Transhumance des "Foulbé" dans les "yaéré". IRCAM.

Mwangi, E., and Ostrom, E. (2009). Top-Down Solutions: Looking up from Africa's Rangelands. Environment 51: 35-44.

Myers, F. R. (1982). Always ask: resource use and land ownership among Pintupi Aborigines of the Australian Western desert. In Williams, N. M., and Hunn, E. S. (eds.), Resource Managers: North American and Australian Hunter-Gatherers. Westview Press, Boulder (CO), pp. 173-195.

Niamir-Fuller, M. (1999a). Introduction. In Niamir-Fuller, M. (ed.), Managing Mobility in African Rangelands: The Legitimization of Transhumance. Intermediate technology, London, pp. 1-9.

Niamir-Fuller, M. (1999b). Towards a synthesis of guidelines for legitimizing transhumance. In Niamir-Fuller, M. (ed.), Managing
Mobility in African Rangelands: The Legitimization of Transhumance. Intermediate technology, London, pp. 266-290.

Nicholson, S. E., Kim, J., and Hoopingarner, J. (1988). Atlas of African rainfall and its interannual variability. Tallahassee (FL): Department of Meteorology, The Florida State University.

Ostrom, E. (1990). Governing the Commons: The Evolution of Institutions for Collective Action. Cambridge University Press, Cambridge (UK).

Ostrom, E. (2007). A Diagnostic Approach for Going Beyond Panaceas. PNAS 104: 15181-15187.

Ostrom, E., Dietz, T., Dolsak, N., Stern, P. C., Stonich, S., and Weber, E. U. (2002). The Drama of the Commons. National Academy Press, Washington, D.C.

Peters, P. E. (1994). Dividing the Commons: Politics, Policy and Culture in Botswana. University Press Virginia, Charlottesville (VA).

Picardi, A. C., and Seifert, W. W. (1976). A Tragedy of the Commons in the Sahel. Technology Review 78: 42-51.

Poteete, A. R., Janssen, M. A., and Ostrom, E. (2010). Multiple Methods in Practice: Research on Collective Action and the Commons. Princeton University Press, Princeton (NJ).

Robinson, L. W. (2009). A Complex-Systems Approach to Pastoral Commons. Human Ecology 37: 441-451.

Ruttan, L. M., and Mulder, M. B. (1999). Are East African Pastoralists Truly Conservationists? Current Anthropology 40: 621-652.

Schlee, G. (2010). "Territorialising ethnicity: the political ecology of pastoralism in Northern Kenya and Southern Ethiopia." In Working Paper, Vol. 121. Max Planck Institute for Social Anthropology, Halle (Germany).

Scholte, P. (2005). Floodplain Rehabilitation and the Future of Conservation and Development: Adaptive Management of Success in Waza-Logone. Leiden University, Cameroon.

Scholte, P. (2007). Maximum Flood Depth Characterises AboveGround Biomass in African Shallowly Flooded Grasslands. Journal of Tropical Ecology 23: 63-72.

Scholte, P., Kirda, P., Adam, S., and Kadiri, B. (2000). Floodplain Rehabilitation in North Cameroon: Impact on Vegetation Dynamics. Applied Vegetation Science 3: 33-42.

Scholte, P., Kari, S., Moritz, M., and Prins, H. (2006). Pastoralist Responses to Floodplain Rehabilitation in Northern Cameroon. Human Ecology 34: 27-51.

Seignobos, C., and Iyébi-Mandjek, O. (eds.) (2000). Atlas de la Province Extrême-Nord Cameroun. IRD \& MINREST, Paris.

Seignobos, C., and Jamin, F. (2003). La Case Obus: Historie et Reconstitution. Patrimoime sans frontière, Marseille (France).

Sinclair, A. R. E., and Fryxell, J. M. (1985). The Sahel of Africa: Ecology of a Disaster. Canadian Journal of Zoology 63: 987-994.

Stenning, D. J. (1957). Transhumance, Migratory Drift, Migration; Patterns of Pastoral Fulani Nomadism. The Journal of the Royal Anthropological Institute of Great Britain and Ireland 87: $57-73$.

Sutherland, W. J. (1996). From Individual Behaviour to Population Ecology. Oxford University Press, Oxford.

Swallow, B. M. (1990). Strategies and Tenure in African Livestock Development. LTC Paper \#140. Land Tenure Center, University of Wisconsin, Madison, Wisconsin.

Turner, M. D. (1999). The role of social networks, indefinite boundaries and political bargaining in maintaining the ecological and economic resiliency of the transhumance systems of SudanoSahelian West Africa. In Niamir-Fuller, M. (ed.), Managing Mobility in African Rangelands. IT Publications, London, pp. 97-123. 